\title{
The History and Continuity of Kuningan Weaving
}

\author{
Fendi Adiatmono ${ }^{1}$, Arif Rivai ${ }^{2}$ \\ ${ }^{1}$ Adi IAI Educational Foundation, Indonesia. \\ ${ }^{2}$ NKRI Foundation, West Java, Indonesia \\ fendiadiatmono@yahoo.com rivai_sm@yahoo.com
}

\begin{abstract}
Human work is influenced by thinking and behavior patterns. Weaving as a result of human culture is no longer something that is considered important. Birth and development have not been comprehensively explored. Kuningan as a weaving region cannot be separated from the problem. Its development stalled during Colonial rule.

This research aims to describe the development of weaving as a home industry in terms of cultural history, form of motives and management. This study aims to (1) describe the weaving motif in the Kuningan home industry; and (2) design forms of motifs that are in accordance with the history of Kuningan culture; and (3) suitable management of art applied to the Kuningan area. This research is a qualitative research where the data obtained from observations, interviews, documentation, and participant observations are presented in descriptive form. The instruments in this study were the researchers themselves with guidelines for observation, interviews, and documentation. The tools used in this study are digital cameras and writing equipment. The validity of the data from this paper is obtained by perseverance / regularity of observation and publication of research results. Analysis of the data used in the form of reduction, presentation of data, and conclusion. The results of this study indicate (1) the weaving motifs of home industry production are not in accordance with the development of other textile arts, such as batik. Then the form of the motive produced is the result of interference from outside countries; and (2) Kuningan home industry weaving is not in the right management, as evidenced by the death of the industry in the present.

This research uses the theory of visual history and methods of anthropological approaches, forms of aesthetics, and symbols that are relevant to the subject and subject matter of the problem. So, the context that was built to be legitimate, text, oral and visual, both now and past has been used as a reconstruction. The contents of the study and his work aroused community sensitivity in formulating natural and human development constructions. The general objective of this research is the point of awareness, that it creates filters, balance, and makes a counter of global forces that try to make Indonesian society artificial.

This research is expected to emit reference needs for public creativity in general. The written phrases are expected to be able to inspire the sensitivity of the people of Indonesia, to further dynamize the transmission method in the construction of the community.
\end{abstract}

Keywords : weaving; history; motive; management.

\section{Introduction}

The western part of Java, Kuningan, has natural and human resources, which if properly utilized result in a strong economy. Kuningan people are naturally creative and talented, which is why many of them are involved in various creative trades. Skills and talents are creatively used in the production of traditional handicrafts and this creates a "Creative Industry". The creative industry is an industry that comes from them in their creativity, skills and individual talents and has the potential for wealth and job creation through the generation and exploitation of intellectual property. Creative industries such as blacksmithing, goldsmithing, pottery, tanning and leather carving, wood carving and, are typical examples commonly found in local Indonesian environments. 
There are several areas in Kuningan where many aspects of textile work are carried out. Traditional textile works such as weaving, batik, and embroidery garments (both hands and machines), many people are involved in all these works and therefore produce a decent life without having to depend on anyone. Although the country has many ethnic groups, there is no big difference in folk textiles; this is because it is produced in all parts of the region.

Historically, the Kuningan people carried out activities in the form of textile production for sociological needs and protecting the body, which later in the century developed into a form of Colonial order. His desire to use durable materials leads to the appearance of hand woven fabrics. After that, weaving looms are used in production. Then, the economic interests of textiles in the country became the focus and this led to a variety of artistic ornaments.

Research problems have been formulated, as written below.

1. How is the development of Kuningan weaving products?

2. Why is there stagnation in the field of design and marketing?

The purpose of this study is to grow the transmission culture of woven products in Kuningan in a more qualified and scientific manner.

The benefits of this research are technology products in the form of woven motifs that can be utilized by stakeholders, through rebuilding the Kuningan weaving industry and producing scientific publications, booklets, IPRs and teaching materials.

\section{Material and Methods}

\subsection{Material}

All that is asked for woven, its form is a form that forms a certain motive, all of which are called ornaments. Ikat weaving is a form of home industry that is known for generations. The making of woven fabric is traditionally carried out by rural communities and has become part of their daily activities. To make ikat fabric, dyes are needed which will give a pattern and motif from the fabric made. Many types of plants and animals that have beautiful and brilliant colors. The use of dyes derived from plants and animals has been carried out by weaving craftsmen, but the most widely used ones are from the leaves of plants obtained from the forest. The use of natural dyes in the manufacture of woven fabric is more popular than synthetic dyes because it can provide its own privileges. In addition, the use of natural dyes can provide several benefits, because it is not toxic to the skin, cheaper and durable. Some examples of plants that are often used by ikat weavers as coloring material are the red color of young teak leaves and cassowary bark, brownish red from areca nut roots and the yellow color of the turmeric and noni root roots. Some examples of these natural dyes, by the weaving craftsmen, have been tested for stability through washing in detergents which have not faded. Tie weaving with natural coloring material is one form of traditional knowledge of society that needs to be supported by scientific research, so that it can be better preserved and developed. Based on the background, the purpose of this study is to find out the weaving technique, composition and coloring elements, and marketing that is done.

\subsection{Methods}

This research method is written following the correct method with carefully describe the methods and procedures for collecting and or information, processing data and / or information, drawing conclusions and formulating suggestions and opinions. Schedule and 
stage of research activities to be carried out which contains the name of the activity and the time of implementation of the activity in detail.

In Kuningan weaving study, historical studies are needed, as a support for the preservation of cultural subjects. To understand the shape of the motives, anthropological and aesthetic approaches are needed. Therefore, this study uses multidisciplinary approaches and theories as follows.

\section{A. Approach to Art History}

The history of Kuningan culture is an event in gaining new evidence regarding ornaments. Edi S. Ekadjati, in History of Kuningan (2003), explained that the Kuningan people have characteristics in several ways, both daily life and customs. F Adiatmono in Kuninganology (2017), describes that the kunigan clothing model consists of daily clothes, clothing for cultural ceremonies, clothing for worship, and war clothing. In essence the meaning in the form of clothing is the result of reflection of the world his life. In the data processing section, periodic methods are used which are deemed capable of parsing every thing related to the presence of weaving in Kuningan.

\section{B. Anthropological Approach to Art}

Work is work mainly the result of artistic activities. The craft weaving is something that is made by hand made from yarn and is very beautiful. This type of applied art focuses on hand skills to process raw materials around the environment into objects that have functional and aesthetic value. Kriya himself uses a lot of expertise in pure art such as ways to carve, sculpt to produce a product, by not paying too much attention to emotional satisfaction. Thus, the approach of Fendi Adiatmono in Weeskamer (2014), is used in the field of art anthropology in the field of weaving by designing the design and its relationship with the creator of the design and the influencing factors.

\section{Aesthetic Theory}

Using $\mathrm{F}$ Adiatmono and Arif Rivai's at Extinction of Kuningan Weaving in the Neighborhood of the Fashion Industry (2017), art theory that history and visual weaving can be a function of social, economic, and aesthetic history.

\section{Results and Discussion}

\subsection{Results}

Textiles are no longer produced only for the body of protection, but for decoration as well. Maiwada (2009) states that modern-day Scholars believe that the dress gives a sign of identity and through which non-verbal messages are communicated. It also believes that in traditional societies, the function of clothing is almost as a language that can indicate a person's age, gender, and marital status, place of origin, religion, and social status. He says that, clothing and accessories are the most important forms of aesthetic expression. Clothes and accessories not only cover the body, it shows the sex, character, wealth, and status of a person.

Weaving is one of several types of textile products that received a positive response in the community. Indonesian woven fabrics have experienced a long history along with the development of the peradap community in an area. In the past, in Kuningan the fabric of woven fabric in the community was as traditional clothing such as wedding ceremonies, custom equipment, and European orders. 
The close relationship between textiles and culture extended to a time when many islanders who came into contact with the culture that used bronze came from areas that are now the northern part of Vietnam [Wanda Warming and Gaworski, 1981, p. 54].

The cultural factors are one of the contributing factors 'choosing to make ikat woven cloths' as a system of livelihood for their lives, namely cultural factors, which are known according to the information given that work is passed down from their parents or ancestors. Knowledge in making ikat woven cloth is not because of formal education but because of knowledge that is passed down from ancestors.

\subsection{Discussion}

Weaving craft is one of Indonesia's traditional cloth culture arts produced in various regions throughout the archipelago. Weaving has high meaning, historical value, and technique in terms of color, motif, and type of material and yarn used and each region has its own characteristics. Weaving as one of the high cultural heritage is the pride of the Indonesian people, and reflects the national identity. The style of ancient Kuningan area, which is found on the dragon stone reliefs on Mount of Tillu in Kuningan, can be taken as a theme and concept of creation in the form of a weaving motif.

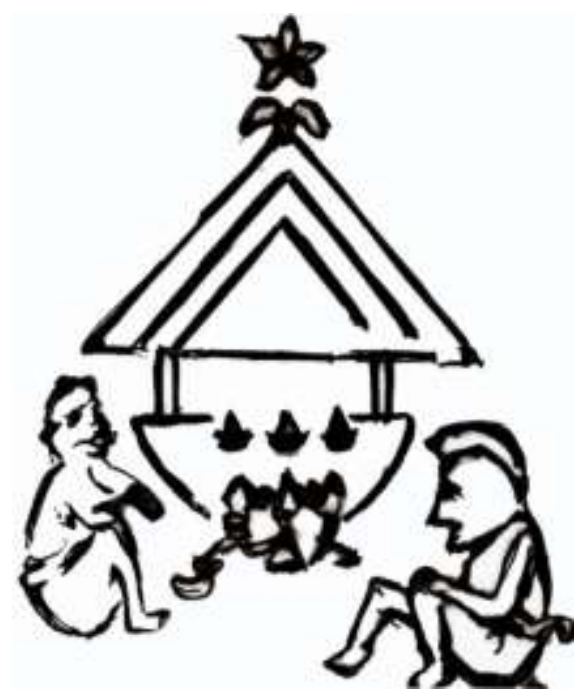

Fig. 1. The traditional Kuningan ritual in front of their traditional house on the Stone Dragon site (F Adiatmono, 2017) 


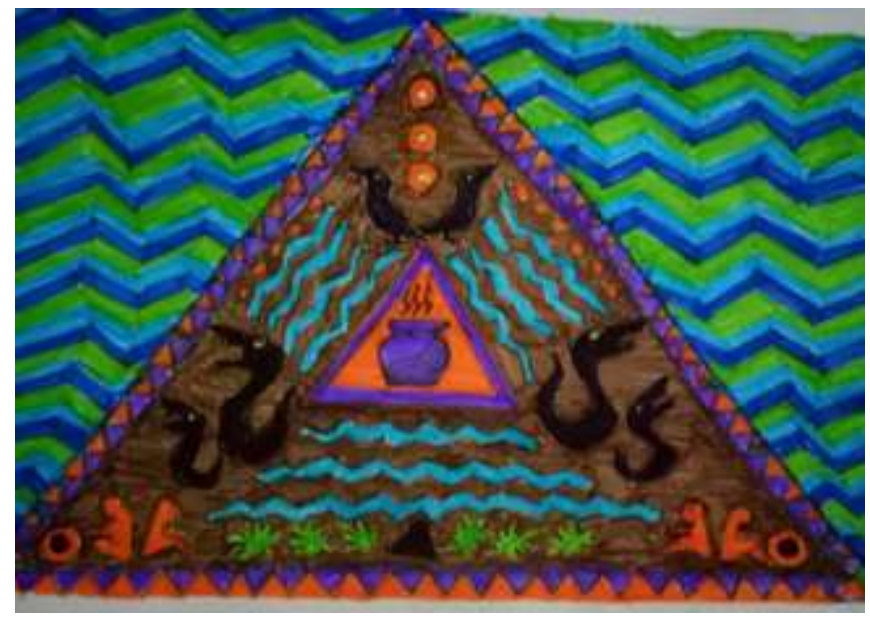

Fig 2. The design becomes an exploration of the motifs of the history of Kuningan (Arif Rivai, 2018)

Cultural factors are one of the contributing factors for making ikat woven fabrics as a system of livelihood for their lives, namely cultural factors, which are known according to the information given that work is passed down from their parents or ancestors. Knowledge in making ikat woven cloth is not because of formal education but because of knowledge that is passed down from ancestors.

Weaving crafts have been known before the days of the first Hindu kingdom in Indonesia. This fabric is believed to be carried by migrants from Vietnam and Cambodia who brought the Dongsong culture to Indonesia. Not only that, the development of woven fabrics in Indonesia began to occur when the trading system entered the Indonesian archipelago. Starting from the $5^{\text {th }}$ century when Hindu Buddhists entered the Indonesian region.

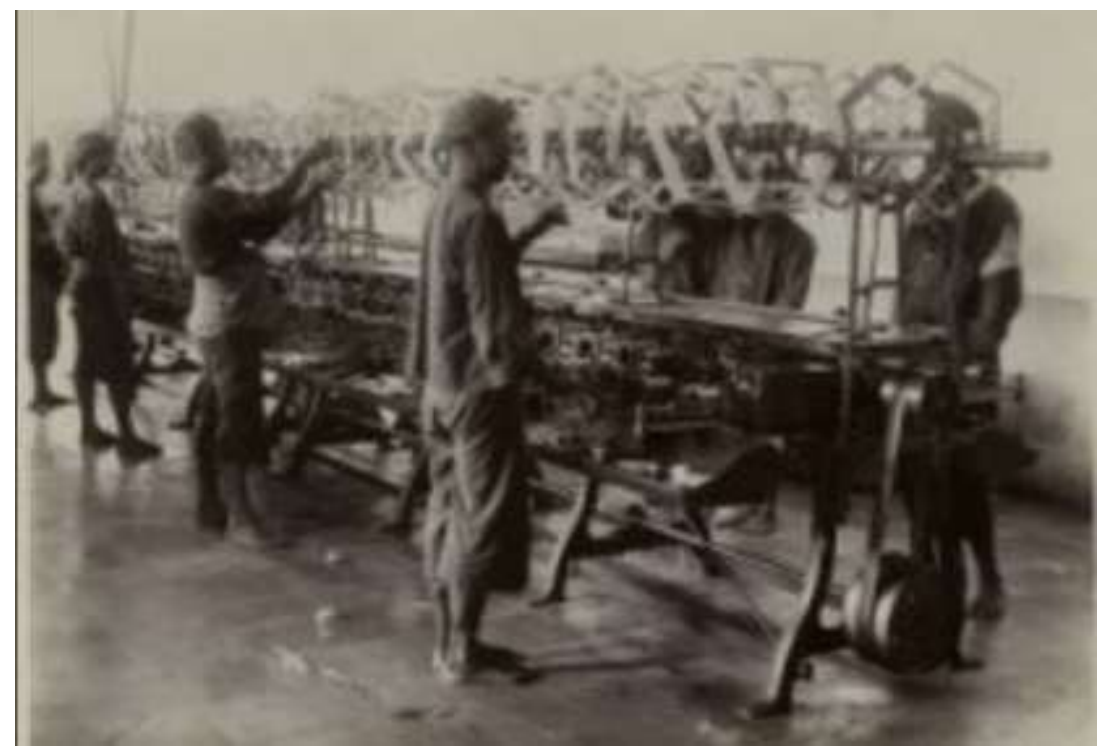

Fig. 3. Textile products (modern weaving) in Kuningan (KITLV Leiden 1920) 
Woven motifs produced by Kuningan people from Kuningan prisons are the work of an intellectual arrangement.

If traced back from the motives, techniques, manufacturing processes and origin, a ikat woven cloth for the community can be considered to have values and meanings in that value, including spiritual values (religio-magi), political values (associated with traditional rituals and by traditional stakeholders), and socio-economic values (as customary fines to restore social balance). Also deep meaning can be found in the use of woven fabric based on the pattern of the motif.

\section{Conclusions}

The uniqueness of Indonesian culture and the wealth of its natural resources attract foreign countries in the world. No doubt, many things that have happened in the hundreds of years with the exploration of foreign countries in Indonesia (including Kuningan), have added knowledge in various fields. One of these updates occurred in the field of making woven fabrics. Updates on fabric-making techniques in Indonesia are supported by various raw materials and new tools introduced by foreign nations visiting Indonesia.

Regarding the factors that emerged until the weaving was triggered in the history of Kuningan, it can be identified through several factors, namely as written as follows.

1. Cultural Factors

It is a way of life that develops and is shared by a group of people and is passed down from generation to generation. Culture is formed from many complex elements, including the system of religion, politics, customs, language, clothing, buildings and works of art. Culture is a comprehensive lifestyle. Culture is complex, abstract and broad. This sociocultural element is large and includes many community social activities

2. Economic Factors

Being the cause of making weaving and is considered capable of producing material as a living capital and improving the people's economy.

3. Esthetic Factors

It is a form of expression of beauty when Kuningan people try to decorate themselves with certain accessories, such as weaving.

4. Lifestyle Factors

It is a form of behavior, which applies something to be used as a social life pattern in everyday life or is used and applied in certain moments, such as custom rituals and certain forms of association.

5. Colonial Pressure Factors

It is a factor in the formation of several weaving motifs, due to the existence of colonial mastery and conditioned to enter into a work scope for making weaving. This oppression produced the effect of colonial prosperity and on the other hand there was an acceleration of the knowledge of the field of design and engineering of weaving from the Kuningan people. This is based on KITLV data and its description, it is known that the emergence of Kuningan weaving is in the Kuningan prison. If you look at the comparison, it is like the Romusha Japanese era and the Rodi Dutch era.

6. Economic policy in Kuningan, should be focused on the creative industry. If there is a shift towards craft work that is more of a craft product, then the emphasis is on focusing on prioritizing skills and techniques. Given the government's recognition that creative industries lack workers with techniques, calculations, computing and IT capabilities. 
The policy focus at this time has shifted to accommodate the demands of employers in a group of trained craft workers. The existence of new innovations in the field of art management, it is possible that craft workers who produce crafts will be under the inherent supervision of the government. and entrepreneurs in the coming period. This is only to ensure that organizations and practices can be adapted to the demands of optimism in the present, called 'creative economy'.

Woven motifs produced by Kuningan people from Kuningan prisons are the work of an intellectual arrangement. The depiction of the front house ornament motifs shows that the weaving logic is inherent in it capable of capturing the substance of the structure and anatomy of the basic forms of nature that surround them, then poured into simple and core / substantive visual language (F Adiatmono, $2015: 15$ ).

F Adiatmono (2017: 18) probing Kuningan through the prehistoric times of Neolithicum and the Megalithic stone which existed around 3,500 BC. The Cipari region in 1972 was proof of the existence of that life. He continued, accompanied by emphasis through vignettes to sharpen the history of Kuningan art with the expression that human relations with surrounding habitats are based on the assumption that their existence lives in nature which is seen as an orderly and hierarchically arranged order in a culture that is always maintained.

The function of woven fabric in aspects of life are: a) Social Aspects. In the social aspect woven fabrics are widely used for traditional ceremonies such as birth, marriage, or death. Even the symbol and color have been adjusted. b) Economic Aspects. Woven fabrics in economic aspects are used as a means of exchange. Exchange in the sense of goods exchanged with other items. c) Aspects of Identity and Aesthetics. These are two points that are mutually supportive, referring to the work that is compared with other multidisciplinary sciences.

\section{References}

[1]. Adiatmono, Fendi, and Nandarina, Setra, Yogyakarta: Deepublish, 2017.

[2]. Adiatmono, Fendi, and Rivai, Arif, Extinction of Kuningan Weaving in the Neighborhood of the Fashion Industry. Yogyakarta: Deepublish, 2017.

[3]. Adiatmono, Fendi and Rivai, Arif, Pradakon, Yogyakarta: Deepublish, 2017.

[4]. Adiatmono, Fendi, Batik of Kuningan, Yogyakarta: Deepublish, 2017.

[5]. Adiatmono, Fendi, Kuninganology, Yogyakarta: Deepublish, 2017.

[6]. Adiatmono, Fendi, Qualitative Writing Method of Art. Yogyakarta: Deepublish, 2016.

[7]. Adiatmono, Fendi, "The Weapons Kingdom of Kuningan". In International Conference "Education and Cultural Heritage" ICECH. 4 November 2017. Brussels Belgia.

[8]. Adiatmono, Fendi, Ornament. Yogyakarta: Deepublish, 2016.

[9]. Ekadjati, Edi S, History of Kuningan, Bandung: Kiblat Buku Utama, 2003.

[10]. Maiwada, S., 'Embroidered Hand Garment: A beneficial shift for Hausa women in Zaria City', Art and Idea Journal, Department of Fine Arts Obafemi Awolowo University, Ile-Ife, Osun State. Vol. 12, pp. 1-19, July. 2008.

[11]. W. Warming, and M. Gaworski, The World of Indonesian Textile, Tokyo: 1981. 